\title{
Studies on Development of Specific Micronutrient Formulation for Growth and Yield of Potato (Solanum tuberosum L.)
}

\author{
R.P. Manjunath ${ }^{1 *}$, Vishnuvardhana ${ }^{2}$, M. Anjanappa ${ }^{3}$, \\ G.K. Ramegowda ${ }^{4}$ and S. Anilkumar
}

${ }^{1}$ Department of Vegetable Science, College of Horticulture, UHS Campus, GKVK Post, Bengaluru-560065, Karnataka, India

${ }^{2}$ ADRE, RKREC, Bengaluru-65, Karnataka, India

${ }^{3}$ University of Horticultural Sciences Bagalkot-587104, Karnataka, India

${ }^{4}$ Department of Entomology, ${ }^{5}$ Department of Soil Science, RHREC, Bengaluru-560065, India

*Corresponding author

\begin{tabular}{|l|}
\hline K e y w o r d s \\
Micronutrients, \\
$\begin{array}{l}\text { Solanum } \\
\text { tuberosum, } \\
\text { Drymatter }\end{array}$ \\
\hline Article Info \\
\hline $\begin{array}{l}\text { Accepted: } \\
12 \text { October } 2018 \\
\text { Available Online: } \\
10 \text { November } 2018\end{array}$ \\
\hline
\end{tabular}

\section{A B S T R A C T}

A field experiment was conducted at Horticulture Research and Extension Centre (HREC), Somanahallikaval, Hassan during 2016 to study the effect different micronutrients and their formulation on growth, yield and quality of potato (Solanum tuberosum L.) Cv. KufriJyoti. The experiment was conducted with Randomized Complete Block Design with twelve treatments and three replication. Treatments included were $\mathrm{T}_{1}$ (control)- RDF (FYM 25 t/ha + N:P:K at 75:75:100 kg/ha), $\mathrm{T}_{2}: \mathrm{T}_{1}+$ boron, $\mathrm{T}_{3}: \mathrm{T}_{1}+$ zinc, $\mathrm{T}_{4}: \mathrm{T}_{1}+$ zinc + boron, $\mathrm{T}_{5}: \mathrm{T}_{1}+$ IIHR vegetable special, $\mathrm{T}_{6}: \mathrm{T}_{1}+$ IIHR potato special, $\mathrm{T}_{7}: \mathrm{T}_{1}+$ UHSB $1, \mathrm{~T}_{8}$ : $\mathrm{T}_{1}+$ UHSB 2, $\mathrm{T}_{9}: \mathrm{T}_{1}+\operatorname{UHSB} 3, \mathrm{~T}_{10}: \mathrm{T}_{1}+\operatorname{UHSB} 4, \mathrm{~T}_{11}: \mathrm{T}_{1}+\mathrm{UHSB}$ 5, and $\mathrm{T}_{12}:$ RDF of $\mathrm{N}: \mathrm{P}: \mathrm{K}$ without FYM. In each formulation different concentration of micronutrients were used. The micronutrients and their formulation were sprayed at 30, 45 and 60 days after sprouting of tubers. Among the different formulations, $\mathrm{T}_{11}$-foliar spray of UHSB-5 micronutrient formulation along with RDF recorded the maximum plant height $(66.87 \mathrm{~cm})$ whereas, $\mathrm{T}_{9}$-foliar spray of UHSB-3 micronutrient formulation along with RDF recorded significantly highest number of branches per plant (4.60), number of compound leaves per plant (24.67) and plant canopy spread $\left(1612.64 \mathrm{~cm}^{2}\right)$ at 60 days after sprouting of tubers. Same treatment was also recorded significantly highest tubers per plant (7.87), tuber weight per plant $(687.87 \mathrm{~g} /$ plant $)$, tuber yield per hectare $(25.18 \mathrm{t} / \mathrm{ha})$ and dry matter content $(19.76 \%)$.

\section{Introduction}

Potato is a very popular vegetable grown all over the world and is an important food crop grown in more than 150 countries in the world. Potato (Solanum tuberosum L.) is an important food crop after wheat, maize and rice, contributing to food and nutritional security in the world. It is also called as poor man's strength or king of vegetables (Mustafa, 1997).

Potato developed as a temperate crop and was later distributed throughout the world. It was 
introduced to India by early $17^{\text {th }}$ century probably through British missionaries or Portuguese traders. India is now producing 43.77 million tonnes of potato tubers in an area about 2.13 million hectare (Anon., 2016).

Nutrient management in potato is very important to achieve optimum yield and quality of tubers. Potato is a plant with high nutrient demands because of forming abundant vegetative mass and a high quantity of tubers per unit area. It is a great consumer of nitrogen, phosphorus, potassium, magnesium and calcium, as well as micro nutrients. High potato yields can only be obtained through the application of optimal nutrient doses in balanced proportions (Poljak et al., 2007). But Indian agricultural production heavily depends on fertilizer application which results in greater rate of nutrient collapse and soil health problems. Regular depletion of nutrient resources from soils has led to emergence of several nutrient deficiencies. Most of the Indian soils are widely deficient in micronutrients especially $\mathrm{Zn}, \mathrm{Mn}, \mathrm{B}$ and Fe. The efficiency of applied inorganic micronutrients is rather low due to their fixation in the soil.

However, soil mineral reserves and soil fertilization are not always sufficient to satisfy the needs of crops. Nutritional disorders in potato occur in acidic and alkaline soils. In acidic soils, there is a lack of calcium, magnesium and phosphorus for growing crop and in alkaline soil there is lack of boron, manganese and zinc. The alternative approach is the application of these nutrients to plant leaves and stems through foliar fertilization.

Micronutrients play a very important role in vital processes of plants. They increase the chlorophyll content of leaves, improve photosynthesis which intensify the assimilating activity of the whole plants (Marschner, 1995). Spray of micro-element solution $(\mathrm{B}, \mathrm{Cu}, \mathrm{Mn}, \mathrm{Zn}$ and $\mathrm{Mo}$ ) on potato leaves increased the uptake of $\mathrm{N}, \mathrm{P}, \mathrm{K}$; chlorophyll content and photosynthesis in leaves, promoted the tuber expansion and increase potato yield (Meng et al., 2004).

Thus micronutrients are important key elements which stimulates the uptake of other primary and secondary nutrients when applied in optimal concentration because of their interaction effect like zinc associated with uptake of phosphorous, iron associated with uptake of copper, copper associated with uptake of zinc and iron associated with uptake of magnesium etc. And foliar application of micronutrients readily available to plants moreover easy to apply compared to soil application.

\section{Materials and Methods}

The soil of the experimental area was sandy loam having good physical and chemical properties and $\mathrm{pH}$ of the soil was 6.2. This experiment was undertaken to find out the best micronutrient formulation to obtain good growth, yield and yield attributes in potato. The design followed was RCBD (Randomized Complete Block Design) with 12 treatments replicated thrice in a plot of $4.2 \times 4 \mathrm{~m}$ size with $60 \times 20 \mathrm{~cm}$ spacing during Kharif 2016. The treatments included under the study were, $\mathrm{T}_{1}$ (control)- RDF (FYM 25 t/ha + N:P:K at 75:75:100 kg/ha), $T_{2}-R D F+$ Foliar spray of boron at $50 \mathrm{ppm}, \mathrm{T}_{3}-\mathrm{RDF}+$ Foliar spray of zinc $150 \mathrm{ppm}, \mathrm{T}_{4}-\mathrm{RDF}+$ Foliar spray of zinc $150 \mathrm{ppm}+$ boron $50 \mathrm{ppm}, \mathrm{T}_{5}-\mathrm{RDF}+$ Foliar spray of IIHR vegetable special $(5 \mathrm{~g} / \mathrm{l}), \mathrm{T}_{6}$ RDF + Foliar spray of IIHR potato specific nutrient formulation $(4 \mathrm{~g} / \mathrm{l}), \mathrm{T}_{7}-\mathrm{RDF}+$ Foliar spray of UHSB 1 potato micronutrient formulation $(3 \mathrm{~g} / \mathrm{l}), \mathrm{T}_{8}-\mathrm{RDF}+$ Foliar spray of UHSB 2 potato micronutrient formulation $(3 \mathrm{~g} / \mathrm{l}), \mathrm{T}_{9}-\mathrm{RDF}+$ Foliar spray of UHSB 3 potato micronutrient formulation $(3 \mathrm{~g} / \mathrm{l}), \mathrm{T}_{10}-$ $\mathrm{RDF}+$ Foliar spray of UHSB 4 potato 
micronutrient formulation $(3 \mathrm{~g} / \mathrm{l}), \mathrm{T}_{11}-\mathrm{RDF}+$ Foliar spray of UHSB 5 potato micronutrient formulation $(3 \mathrm{~g} / \mathrm{l})$ and $\mathrm{T}_{12^{-}}$Only recommended dose of N:P:K without FYM. Composition of nutrient formulation is presented in Table 1 and was applied at 30, 45 and 60 days after sprouting of tubers.

\section{Results and Discussion}

\section{Growth parameters}

There was no significant difference between the plant emergence percent among the treatments (Table 2) indicating the uniformity in the plant emergence in the experimental plot before the imposition of treatment. Even then, the plant emergence ranged from 86.78 per cent $\left(\mathrm{T}_{5}-\mathrm{RDF}+\mathrm{FYM}+\mathrm{IIHR}\right.$ Vegetable Special) to 83.71 per cent $\left(\mathrm{T}_{9}-\mathrm{RDF}+\mathrm{FYM}+\right.$ UHSB-3)

Foliar spray of UHSB-5 micronutrient formulation along with soil application of RDF recorded significantly highest plant height at 60 days after sprouting $(66.87 \mathrm{~cm})$ compared to $\mathrm{T}_{1}$-control $(53.80 \mathrm{~cm})$. However, foliar spray of UHSB- 3 micronutrient formulation along with soil application of RDF recorded significantly highest number of branches (4.60), number of compound leaves per plant (24.67), plant canopy spread $\left(1612.64 \mathrm{~cm}^{2}\right)$ at 60 days after sprouting. Meanwhile significantly highest haulm dry matter production was recorded in $\mathrm{T}_{11}$ with $\mathrm{RDF}+\mathrm{FYM}+$ UHSB-5 (3177.78 $\left.\mathrm{kg} \mathrm{ha}^{-1}\right)$ which was on par with $\mathrm{T}_{9}\left(3111.11 \mathrm{~kg} \mathrm{ha}^{-1}\right)$ compared to control with RDF + FYM $\left(2572.22 \mathrm{~kg} \mathrm{ha}^{-1}\right)$.

Similar results were also reported by Vinod Kumar et al., (2008), Basavarajeswari et al., (2008), Sivaiah et al., (2013), Banerjee et al., (2016), Praveen Kumar et al., (2008), Ali et al., (2015), Acharya et al., (2015) and Parmer et al., (2016) in different crops. Plant height may be increased due to application of zinc which plays major role in synthesis of auxin besides the association of boron with development of cell wall and cell differentiation which helps in root and shoot growth of plants (Basavarajeswari et al., 2008; Sharma and Grewal, 1988).

Improvement in growth characters as a result of application of micronutrients might be due to the enhanced photosynthetic and other metabolic activity which leads to an increase in various plant metabolites responsible for cell division and elongation (Hatwar et al., 2003). Mallick and Muthukrishnan (1980) explained that the presence of zinc activates the synthesis of tryptophan, the precursor of IAA and which is responsible to stimulate the plant growth. Iron plays an important role in promoting growth characters, being a component of ferredoxin, an electron transport protein and is associated with chloroplast. It helps in photosynthesis might have helped in better vegetative growth (Hazra et al., 1987).

Increase in number of leaves per plant may be due to the role of micronutrients in cell division, meristematic activity of plant tissue and expansion of cells (Acharya et al., 2015).

Influence of boron either single or in combination with other micronutrients has been reported to increase the number of leaves per plant in several crops (Sivaiah et al., 2013; Manas et al., 2014).

\section{Yield parameters}

Significantly highest numbers of A grade $>75$ $\mathrm{g}$ tubers (4.33 tubers/plant), highest total tubers ( 7.87 tubers/plant), total tuber yield per plant $(687.87 \mathrm{~g})$, total tuber yield per hectare $\left(25.18 \mathrm{t} \mathrm{ha}^{-1}\right)$ and dry matter content of tubers $(19.76 \%)$ was recorded with foliar spray of UHSB-3 micronutrient formulation along with soil application of RDF (Table 3 and 4). 
Table.2 Influence of foliar spray of micronutrients on plant height, number of branches, number of leaves, Plant spread and haulm yield perplant

\begin{tabular}{|c|c|c|c|c|c|c|}
\hline \multirow[t]{2}{*}{ Treatment } & \multirow[t]{2}{*}{$\begin{array}{l}\text { Plant emergence } 30 \\
\text { DAS }(\%)^{* * *}\end{array}$} & $\begin{array}{c}\text { Plant } \\
\text { height (cm) }\end{array}$ & $\begin{array}{l}\text { No. of } \\
\text { branches }\end{array}$ & $\begin{array}{l}\text { No. of } \\
\text { leaves }\end{array}$ & $\begin{array}{c}\text { Plant } \\
\text { spread } \\
\left(\mathrm{cm}^{2}\right)\end{array}$ & \multirow[t]{2}{*}{$\begin{array}{l}\text { Haulm yield } \\
\text { on dry weight } \\
\text { basis (kg/ha) }\end{array}$} \\
\hline & & 60 DAS & 60 DAS & 60 DAS & 60 DAS & \\
\hline $\begin{array}{l}\text { T}_{1}: \text { FYM }(25 \mathrm{t} / \mathrm{ha})+\text { Recommended dose of N: P: K } \\
(75: 75: 100 \mathrm{Kg} / \mathrm{ha}) .\end{array}$ & $\begin{array}{c}84.61 \\
(66.88)\end{array}$ & 53.80 & 2.67 & 20.40 & 1149.71 & 2572.22 \\
\hline$T_{2}: T_{1}+$ Foliar spray of boron at 30,45 and 60 DAS & $\begin{array}{c}84.28 \\
(66.65)\end{array}$ & 56.07 & 3.00 & 22.40 & 1331.59 & 2805.56 \\
\hline$T_{3}: T_{1}+$ Foliar spray of zinc at 30,45 and 60 DAS & $\begin{array}{c}84.29 \\
(66.62)\end{array}$ & 56.80 & 3.53 & 23.67 & 1525.97 & 2766.67 \\
\hline $\begin{array}{l}T_{4}: T_{1}+\text { Foliar spray of zinc }+ \text { boron at } 30,45 \text { and } 60 \\
\text { DAS }\end{array}$ & $\begin{array}{c}84.64 \\
(66.94)\end{array}$ & 61.47 & 3.73 & 21.47 & 1439.53 & 2877.78 \\
\hline $\begin{array}{l}T_{5}: T_{1}+\text { Foliar spray of IIHR vegetable special at } 30 \\
45 \text { and } 60 \text { DAS. }\end{array}$ & $\begin{array}{c}86.78 \\
(68.66)\end{array}$ & 61.00 & 3.07 & 23.07 & 1331.69 & 2927.78 \\
\hline $\begin{array}{l}\mathrm{T}_{6}: \mathrm{T}_{1}+\text { Foliar spray of IIHR potato specific nutrient } \\
\text { formulation at } 30,45 \text { and } 60 \mathrm{DAS} \text {. }\end{array}$ & $\begin{array}{c}85.77 \\
(67.82)\end{array}$ & 63.60 & 3.53 & 23.27 & 1295.56 & 2983.33 \\
\hline $\begin{array}{l}T_{7}: T_{1}+\text { Foliar spray UHSB } 1 \text { potato micronutrient } \\
\text { formulation at } 30,45 \text { and } 60 \text { DAS }\end{array}$ & $\begin{array}{l}85.99 \\
(68.00)\end{array}$ & 64.93 & 3.73 & 22.27 & 1376.75 & 3011.11 \\
\hline $\begin{array}{l}T_{8}: T_{1}+\text { Foliar spray of UHSB } 2 \text { potato micronutrient } \\
\text { formulation at } 30,45 \text { and } 60 \text { DAS }\end{array}$ & $\begin{array}{c}86.48 \\
(68.41)\end{array}$ & 64.80 & 3.67 & 22.60 & 1341.07 & 2955.56 \\
\hline $\begin{array}{l}T_{9}: T_{1}+\text { Foliar spray of UHSB } 3 \text { potato micronutrient } \\
\text { formulation at } 30,45 \text { and } 60 \text { DAS }\end{array}$ & $\begin{array}{c}83.71 \\
(66.25)\end{array}$ & 60.27 & 4.60 & 24.67 & 1612.64 & 3111.11 \\
\hline $\begin{array}{l}\mathrm{T}_{10}: \mathrm{T}_{1}+\text { Foliar spray of UHSB } 4 \text { potato } \\
\text { micronutrient formulation at } 30,45 \text { and } 60 \text { DAS }\end{array}$ & $\begin{array}{l}86.75 \\
(68.64)\end{array}$ & 60.53 & 4.47 & 22.93 & 1285.87 & 2900.00 \\
\hline $\begin{array}{l}T_{11}: T_{1}+\text { Foliar spray of UHSB } 5 \text { potato } \\
\text { micronutrient formulation at } 30,45 \text { and } 60 \text { DAS }\end{array}$ & $\begin{array}{c}85.71 \\
(67.78)\end{array}$ & 66.87 & 4.07 & 23.67 & 1510.65 & 3177.78 \\
\hline $\mathrm{T}_{12}$ : Recommended dose of N:P:K without FYM & $85.71(67.78)$ & 53.33 & 2.53 & 20.73 & 1188.99 & 2483.33 \\
\hline S Em \pm & 0.83 & 2.05 & 0.33 & 0.49 & 74.07 & 53.77 \\
\hline CD 5\% & NS & 6.00 & 0.98 & 1.42 & 217.23 & 157.70 \\
\hline
\end{tabular}


Table.3 Influence of foliar spray of micronutrients on grade wise tuber number per plant

\begin{tabular}{|c|c|c|c|c|c|}
\hline \multirow{2}{*}{ Treatments } & \multicolumn{4}{|c|}{ Grade wise tuber number/plant } & \multirow{2}{*}{$\begin{array}{c}\text { Total tuber } \\
\text { number/ plant }\end{array}$} \\
\hline & $\begin{array}{l}\text { A Grade } \\
(>75 \text { g) }\end{array}$ & $\begin{array}{l}\text { B Grade } \\
(50-75 \text { g) }\end{array}$ & $\begin{array}{l}\text { C Grade } \\
(25-50 \text { g) }\end{array}$ & $\begin{array}{l}\text { D Grade } \\
(0-25 \text { g) }\end{array}$ & \\
\hline $\begin{array}{l}\left.\text { T1 }_{1} \text { FYM ( } 25 \text { t/ha }\right)+ \text { Recommended dose of N:P:K (75:75:100 } \\
\text { Kg/ha). }\end{array}$ & 2.60 & 1.13 & 2.00 & 1.47 & 7.07 \\
\hline$T_{2}: T_{1}+$ Foliar spray of boron at 30,45 and 60 DAS & 3.87 & 0.53 & 1.40 & 0.80 & 6.60 \\
\hline $\mathrm{T}_{3}: \mathrm{T}_{1}+$ Foliar spray of zinc at 30,45 and 60 DAS & 2.67 & 1.53 & 1.07 & 1.13 & 6.20 \\
\hline $\mathrm{T}_{4}: \mathrm{T}_{1}+$ Foliar spray of zinc + boron at 30,45 and 60 DAS & 3.27 & 1.20 & 1.00 & 0.67 & 6.13 \\
\hline $\begin{array}{l}T_{5}: T_{1}+\text { Foliar spray of IIHR vegetable special at } 30,45 \text { and } \\
60 \text { DAS. }\end{array}$ & 2.80 & 1.20 & 0.93 & 1.00 & 5.93 \\
\hline $\begin{array}{l}T_{6}: T_{1}+\text { Foliar spray of IIHR potato specific nutrient } \\
\text { formulation at } 30,45 \text { and } 60 \text { DAS. }\end{array}$ & 3.27 & 1.33 & 1.13 & 0.8 & 6.40 \\
\hline $\begin{array}{l}T_{7}: T_{1}+\text { Foliar spray of UHSB } 1 \text { potato micronutrient } \\
\text { formulation at } 30,45 \text { and } 60 \text { DAS }\end{array}$ & 4.27 & 1.40 & 1.00 & 0.53 & 7.20 \\
\hline $\begin{array}{l}T_{8}: T_{1}+\text { Foliar spray of UHSB } 2 \text { potato micronutrient } \\
\text { formulation at } 30,45 \text { and } 60 \text { DAS }\end{array}$ & 4.13 & 1.47 & 1.00 & 0.13 & 6.60 \\
\hline $\begin{array}{l}T_{9}: T_{1}+\text { Foliar spray of UHSB } 3 \text { potato micronutrient } \\
\text { formulation at } 30,45 \text { and } 60 \text { DAS }\end{array}$ & 4.33 & 1.53 & 1.53 & 0.47 & 7.87 \\
\hline $\begin{array}{l}T_{10}: T_{1}+\text { Foliar spray of UHSB } 4 \text { potato micronutrient } \\
\text { formulation at } 30,45 \text { and } 60 \text { DAS }\end{array}$ & 2.47 & 1.53 & 1.00 & 0.67 & 5.67 \\
\hline $\begin{array}{l}T_{11}: T_{1}+\text { Foliar spray of UHSB } 5 \text { potato micronutrient } \\
\text { formulation at } 30,45 \text { and } 60 \text { DAS }\end{array}$ & 3.53 & 1.53 & 1.53 & 0.40 & 7.00 \\
\hline $\mathrm{T}_{12}$ : Recommended dose of $\mathrm{N}: \mathrm{P}: \mathrm{K}$ without FYM & 2.80 & 0.73 & 1.4 & 1.53 & 6.40 \\
\hline S Em \pm & 0.33 & 0.18 & 0.18 & 0.12 & 0.37 \\
\hline CD 5\% & 1.11 & 0.51 & 0.53 & 0.35 & 1.07 \\
\hline
\end{tabular}


Table.4 Influence of foliar spray of micronutrients total yield per plant, yield per hectare and dry weight of tubers

\begin{tabular}{|c|c|c|c|}
\hline Treatments & $\begin{array}{l}\text { Yield per plant } \\
\text { (g) }\end{array}$ & $\begin{array}{l}\text { Tuber yield } \\
\text { (t/ha) }\end{array}$ & $\begin{array}{l}\text { Dry weight of } \\
\text { tubers }(\%)\end{array}$ \\
\hline$T_{1}:$ FYM (25 t/ha) + RDF of N:P:K (75:75:100 Kg/ha). & 418.33 & 19.18 & $\begin{array}{c}16.86 \\
(48.23)\end{array}$ \\
\hline$T_{2}: T_{1}+$ Foliar spray of boron at 30,45 and 60 DAS & 474.37 & 21.63 & $\begin{array}{l}17.38 \\
(40.66)\end{array}$ \\
\hline $\mathrm{T}_{3}: \mathrm{T}_{1}+$ Foliar spray of zinc at 30,45 and 60 DAS & 475.93 & 21.79 & $\begin{array}{c}18.40 \\
(46.49)\end{array}$ \\
\hline$T_{4}: T_{1}+$ Foliar spray of zinc + boron at 30,45 and 60 DAS & 490.29 & 21.88 & $\begin{array}{c}18.34 \\
(41.11)\end{array}$ \\
\hline $\begin{array}{l}T_{5}: T_{1}+\text { Foliar spray of IIHR vegetable special at } 30,45 \text { and } 60 \\
\text { DAS. }\end{array}$ & 474.45 & 20.53 & $\begin{array}{c}19.35 \\
(44.48)\end{array}$ \\
\hline $\begin{array}{l}T_{6}: T_{1}+\text { Foliar spray of IIHR potato specific nutrient formulation } \\
\text { at } 30,45 \text { and } 60 \text { DAS. }\end{array}$ & 484.47 & 23.12 & $\begin{array}{c}18.75 \\
(43.79)\end{array}$ \\
\hline $\begin{array}{l}T_{7}: T_{1}+\text { UHSB } 1 \text { potato micronutrient formulation at } 30,45 \text { and } 60 \\
\text { DAS }\end{array}$ & 532.63 & 22.11 & $\begin{array}{c}18.20 \\
(36.42)\end{array}$ \\
\hline $\begin{array}{l}T_{8}: T_{1}+\text { Foliar spray of UHSB } 2 \text { potato micronutrient formulation } \\
\text { at } 30,45 \text { and } 60 \text { DAS }\end{array}$ & 636.88 & 24.23 & $\begin{array}{c}19.44 \\
(44.46)\end{array}$ \\
\hline $\begin{array}{l}T_{9}: T_{1}+\text { Foliar spray of UHSB } 3 \text { potato micronutrient formulation } \\
\text { at } 30,45 \text { and } 60 \text { DAS }\end{array}$ & 687.87 & 25.18 & $\begin{array}{c}19.76 \\
(34.09)\end{array}$ \\
\hline $\begin{array}{l}T_{10}: T_{1}+\text { Foliar spray of UHSB } 4 \text { potato micronutrient formulation } \\
\text { at } 30,45 \text { and } 60 \text { DAS }\end{array}$ & 486.89 & 20.75 & $\begin{array}{c}18.02 \\
(39.01)\end{array}$ \\
\hline $\begin{array}{l}T_{11}: T_{1}+\text { Foliar spray of UHSB } 5 \text { potato micronutrient formulation } \\
\text { at } 30,45 \text { and } 60 \text { DAS }\end{array}$ & 625.14 & 24.88 & $\begin{array}{l}18.85 \\
30.82)\end{array}$ \\
\hline $\mathrm{T}_{12}:$ Recommended dose of N:P:K without FYM & 358.44 & 17.18 & $\begin{array}{c}16.33 \\
(52.99)\end{array}$ \\
\hline S Em士 & 11.00 & 0.79 & 0.13 \\
\hline CD 5\% & 32.27 & 2.22 & 0.39 \\
\hline
\end{tabular}

DAS - Days After Sprouting 
Table.1 Composition of nutrient formulation

\begin{tabular}{|c|c|c|}
\hline Sl. No. & Nutrient formulation & Composition \\
\hline 1 & IIHR Vegetable Special & $\begin{array}{l}\text { Zinc ( } 225 \mathrm{ppm}) \text {, Boron (50ppm), Manganese ( } 42.5 \mathrm{ppm}) \text {, Iron (105 ppm), } \\
\text { Copper ( } 5 \mathrm{ppm})\end{array}$ \\
\hline 2 & UHSB-1 formulation & Zinc (50 ppm), Boron (50 ppm), Copper (20 ppm) \\
\hline 3 & UHSB-2 formulation & $\begin{array}{l}\text { Zinc ( } 200 \mathrm{ppm}), \text { Manganese (100 ppm), Boron ( } 50 \text { ppm), Iron ( } 75 \text { ppm), } \\
\text { Copper }(20 \mathrm{ppm})\end{array}$ \\
\hline 4 & UHSB-3 formulation & $\begin{array}{l}\text { Zinc (200 ppm), Manganese ( } 75 \text { ppm), Iron (100 ppm), Boron ( } 75 \text { ppm), } \\
\text { Copper ( } 25 \mathrm{ppm})\end{array}$ \\
\hline 5 & UHSB-4 formulation & $\begin{array}{l}\text { Zinc }(150 \mathrm{ppm}), \text { Manganese }(150 \mathrm{ppm}), \text { Iron }(100 \mathrm{ppm}) \text {, Boron }(75 \mathrm{ppm}) \text {, } \\
\text { Copper }(10 \mathrm{ppm})\end{array}$ \\
\hline 6 & UHSB-5 formulation & $\begin{array}{l}\text { Zinc }(50 \mathrm{ppm}), \text { manganese }(150 \mathrm{ppm}), \text { Iron }(75 \mathrm{ppm}), \text { Boron }(75 \mathrm{ppm}) \text {, } \\
\text { Copper }(25 \mathrm{ppm})\end{array}$ \\
\hline
\end{tabular}

These results are in conformity with Mousavi et al., (2007); Vinod Kumar et al., (2008); Jobori and Hadithy (2014) and Parmar et al., (2016) and Shah et al., (2016)

Increase in tuber yield was due to micronutrient application which may be attributed to the enhanced photosynthesis activity, resulting into the increased production and accumulation of carbohydrates and favorable effect on vegetative growth (Davis et al., 2003; and Basavarajeswari et al., 2008; Parmar et al., 2016) in different vegetable crops.

Increase in tuber size was may be due to improved physiological activity like photosynthesis and translocation of food materials. Applied micronutrients helped in increasing the average weight of individual tuber thereby transferring the tubers from small to medium grade and medium to large grade. Application of micronutrients significantly increased the yield of large and medium grade tubers and decrease proportionately small tubers (Vinod Kumar et al., 2008 and Bari et al., 2001).

In potato, the biomass and tuber yield were highest at adequate $(0.55 \mathrm{mg} / \mathrm{l})$ manganese which appears to be optimum for improved crop yield. Both low and excess Mn resulted in low concentration of chlorophyll $\mathrm{a}$ and $\mathrm{b}$ as well as reduced Hill reaction activity in potato leaves (Gopal et al., 2006). The decline in biomass at both low and high $\mathrm{Mn}(<>0.55$ $\mathrm{mg} / \mathrm{l}$ ) might be due to lower photosynthetic efficiency of potato, because low as well as excess Mn decrease the rate of photosynthesis as $\mathrm{Mn}$ is directly related to biological and economic yield (Marschner, 1995).

By this experiment we can conclude that foliar application of UHSB-3 micronutrient formulation $(3 \mathrm{~g} / \mathrm{l})$ along with soil application of RDF $(75: 75: 100 \mathrm{~kg} / \mathrm{ha}$ of $\mathrm{N}: \mathrm{P}: \mathrm{K})$ and FYM (25 t/ha) was found more economical in terms of plant growth and yield parameters like number of leaves, number of branches, plant canopy spread, Tuber number per plant and tuber yield.

\section{References}

Acharya, U., Venkatesan, K., Saraswathi, T. and Subramanian, K. S., 2015, Effect of zinc and boron application on growth and yield parameters of multiplier onion (Allium cepa L. var aggregatum Don.) var. CO (On) 5. Int. J. Res., 2(1): 757765. 
Ali, M. R., Mehraj, H. and Uddin, A. F. M. J., 2015, Effects of foliar application of zinc and boron on growth and yield of summer tomato. J. Biosci. Agric. Res., 6(1): 512-517.

Annonymous, 2016, $3^{\text {rd }}$ advanced estimates for 2015-16. National Horticulture Board, Gurgaon, 1 p.

Banerjee, H., Sarkar, S., Deb, P., Dutta, S. K., Ray, K., Rana, L. and Majumdar, K., 2016, Impact of zinc fertilization on potato (Solanum tuberosum L.) yield, zinc use efficiency, quality and economics in entisol of West Bengal. $J$. Indian Soci. of Soil Sci, 64(2): 176-182.

Bari, M. S., Rabbani, M. G., Rahman, M. S., Islam, M. J. and Hoque, M. R., 2001, Effect of zinc, boron, sulphar and magnesium on growth and yield of potato. Pak. J. Biol. Sci., 4(9):10901093.

Basavarajeshwari, C. P., Hosamani, R. M., Ajjappalavara, P. S. and Naik, B, H., 2008, Effect of foliar application of micronutrients on growth and yield components of tomato (Lycopersicon esculentum Mill.). Karnataka J. Agric. Sci., 21(3): 428-430.

Davis, T. M., Sanders, D. C., Nelson, P. V., Lengnick, L. and Sperry, W. J., 2003. Boron improves growth, yield, quality and nutrient content of tomato. J. Am. Soc. for Hort. Sci., 128(3): 441-446.

Gopal, R., Dube, B. K. and Chatterjee, C., 2006, Effect of manganese stress on yield, productivity and metabolism of potato. Indian J. Hort., 63(2): 174-177.

Hatwar, G. P., Gondane, S. M., Urkade, S. M. and Gahukar, O. V., 2003, Effect of micronutrients on growth and yield of chilli. J. Soils and Crops, 13(1): 123125.

Hazra, P., Maity, T. K. and Mandal, A. R., 1987, Effect of foliar application of micronutrients on growth and yield of okra (Abelmoschus esculentus L.). Prog. Hort., 19(3-4): 219-222.

Jobori, M. M. and Hadithy, S. A., 2014, Response of potato (Solanum tuberosum) to foliar application of iron, manganese, copper and zinc.Int. J. Agril. Crop Sci., 7(7): 358-363.

Mallick, M. F. R. and Muthukrishnan, C. R., 1980, Effect of micronutrients on the quality of tomato (Lycopersicon esculentum Mill.). Veg. Sci., 7: 6-13.

Manas, D., Bandopadhyay, P. K., Chakravarty, A., Pal, S. and Bhattacharya, A., 2014, Effect of foliar application humic acid, zinc and boron on biochemical changes related to productivity of pungent pepper (Capsicum annum L.). African J. Pl. Sci., 8(6): 320-335.

Marschner, H., 1995, Mineral nutrition of higher plants. $2^{\text {nd }}$ Ed. Academic Press, London $889 \mathrm{p}$.

Meng, M. L., Yic, M. F., Jun, Y. and Lin, Y. Z., 2004, Research Progress on cultivation Physiology of potato in China 5th world Potato Congress, August (2004), 16 p.

Mousavi, S. R., Galavi, M. and Ahmadavand, G., 2007, Effect of zinc and manganese foliar application on yield quality and enrichment on potato (Solanum tuberosum L.). Asian J. Pl. Sci., 6(8): $1256-1260$

Mustafa, G., 1997, Input management of potato crop in Northern areas of Pakistan. M. Sc. thesis, Uni. of Reading. UK. 14. p.

Parmar, M., Nandre, B. M. and Pawar, Y., 2016, Influence of foliar supplementation of zinc and manganese on yield and quality of potato, Solanum tuberosum L. Int. J. Farm Sci., 6(1): 6973.

Poljak, M., Herak-Custic, M., Horvat, T., Coga, L., Magic, A., 2007, Effects of nitrogen nutrition on potato tuber 
composition and yield. Cereal Res. Communications, 35: 937-940.

Praveen Kumar, Pandey, S., Singh, S. and Kumar, D., 2008, Evaluation of nutrient management option for potato processing cultivars. Potato J. 35 (1 2): 46-52.

Shah, S. A., Mohammad, W., Shahzadi, S. R., Elahi, R., Ali, A., BASIR, A. and Haroon, 2016, The effect of foliar application of urea, humic acid and micronutrients on potato crop. Iran Agric. Res., 35(1): 89-94

Sharma, U. C. and Grewal, J. S., 1988, Relative effectiveness of methods of micronutrients application to potato. $J$. Indian Soc Sci., 36 (1): 128-132.

Sivaiah, N. K., Swain, S. K., Raju, B. and Varma, V. S., 2013, Influence of micronutrients application on growth and seed yield in tomato (Lycopersicon esculentum Mill.). Int. J. Development Res., 3(11): 191-195.

Vinod Kumar, Vyakarnahal, B. S., Basavaraj, N., Srikant, K. and Gouda, S. M., 2008, Influence of micronutrients on growth and yield of potato (Solanum tuberosum) cultivars. Indian J. Agric. Sci. 78(9): 752-6.

\section{How to cite this article:}

Manjunath, R.P., Vishnuvardhana, M. Anjanappa, G.K. Ramegowda and Anilkumar, S. 2018. Studies on Development of Specific Micronutrient Formulation for Growth and Yield of Potato (Solanum tuberosum L.). Int.J.Curr.Microbiol.App.Sci. 7(11): 1633-1641. doi: https://doi.org/10.20546/ijcmas.2018.711.185 